\title{
Pemecahan Masalah dalam Menyelesaikan Soal Jumping Task ditinjau dari Gaya Kognitif
}

\author{
Hobri $^{1 *}$, Dianita Tussolikha ${ }^{2}$, Ervin Oktavianingtyas ${ }^{3}$ \\ 1,2,3 Program Studi Pendidikan Matematika, FKIP Universitas Jember \\ *hobri.fkip@unej.ac.id
}

\begin{abstract}
Abstrak
Diberikannya jumping task (JT) merupakan salah satu upaya untuk meningkatkan kemampuan pemecahan masalah siswa. Penelitian deskriptif kualitatif dilakukan untuk menggambarkan dan menganalisis kemampuan siswa dalam memecahkan masalah matematika, baik yang bergaya kognitif field dependent (FD) dan field independent (FI). JT adalah soal dengan level tingkat tinggi, C4-C6 dalam taksonomi Bloom topik Sistem Persamaan Linier Tiga Variabel (SPLTV). Subjek dalam penelitian ini adalah siswa kelas X MIPA 1 SMA Negeri 4 Jember dengan 30 siswa yang terdiri dari 5 siswa FD dan 25 siswa FI. Metode pengumpulan data menggunakan tes (soal JT) dan wawancara. Hasil penelitian menunjukkan perbedaan kemampuan subjek FD dan FI dalam tahap melaksanakan rencana penyelesaian dan memeriksa kembali, yaitu subjek FI mempunyai kemampuan pemecahan yang lebih baik jika dibandingkan subjek FD dalam tahap merencanakan penyelesaian dan memeriksa kembali, sedangkan pada tahapan Polya yang lain tidak ada perbedaan.
\end{abstract}

Kata kunci: gaya kognitif, jumping task, pemecahan masalah matematis

\begin{abstract}
The provision of jumping tasks (JT) is an effort to improve students' problem-solving abilities. Descriptive qualitative research was conducted to describe and analyze students' ability to solve mathematical problems, both in the field-dependent cognitive style (FD) and independent field (FI). JT is a high-level question, C4-C6, in Bloom's taxonomy on the Three Variable Linear Equation System topic. The subjects in this study were students of class X MIPA 1 of SMA Negeri 4 Jember with 30 students consisting of 5 FD students and 25 FI students. The data collection method uses tests (JT questions) and interviews. The results showed the differences in FD and FI subjects' ability in the stages of carrying out the plan of completion and re-checking, i.e., the FI subject had better solving ability than the FD subject in the stage of planning the completion and re-checking. In contrast, at the other Polya stages, there were no differences.
\end{abstract}

Keywords: cognitive style, jumping task, mathematical problem solving

Received: March 14, 2020 / Accepted: June 16, 2020 / Published Online: July 30, 2020

\section{Pendahuluan}

Pemecahan masalah adalah aspek yang sangat penting dalam penerapan dan pengintegrasian konsep matematika dan juga dalam kemampuan membuat keputusan (Tambychik \& Meerah, 2010). Pemecahan masalah adalah sarana yang dipergunakan seseorang menyelesaikan persoalan tidak biasa, dengan menggunakan pengetahuan 
(knowledge), keterampilan (skill), dan pemahaman (understanding) yang dimiliki (Krulik \& Rudnick, 1995). Polya (dalam Hobri dkk., 2020) mendefinsikan pemecahan masalah adalah upaya mencari jalan keluar atas persoalan kompleks dan tentuya solusi yang dituju tidak begitu saja mudah untuk didapatkan. Berdasarkan uraian di atas, kemampuan pemecahan masalah adalah kinerja/performance dalam menyelesaikan persoalan (problem) yang tidak biasa secara langsung atau dengan mudah menerapkan pemahaman (pengetahuan dan keterampilan) yang dimiliki selama ini.

Hasil survei PISA (Programme for International Student Assessment) menunjukkan bahwa kemampuan pemecahan masalah anak-anak atau siswa di Indonesia masih rendah. Hasil PISA tersebut adalah salah satu tolak ukur dalam menganalisis kemampuan pemecahan masalah matematika. PISA 2018 menunjukkan bahwa peringkat Indonesia adalah 73 dari 79 negara. Indonesia memiliki skor rata-rata 379, sedangkan skor rata-rata international adalah 489 (OECD, 2019). Panjaitan dan Rajagukguk (2017) mendapatkan temuan penelitian, hanya 4 orang dari 38 siswa SMA yang mempunyai kemampuan pemecahan masalah dengan kategori sedang, sedangkan 34 siswa lainnya kemampuan pemecahan masalahnya rendah.

Guru dan siswa perlu untuk mengerti, memahami, dan bahkan sampai pada tindakan dapat mengaplikasikan tahapan pemecahan masalah, sehingga mampu memecahkan masalah yang ada dengan baik. Dalam konteks ini, 4 langkah Polya dipergunakan untuk menganalisis kemampuan siswa mengerjakan soal. Empat langkah Polya tersebut dijelaskan berikut: (1) bagaimana memahami suatu masalah dengan baik, (2) bagaimana merencanakan penyelesaian berdasarkan apa yang diketahui dan ditanyakan, (3) bagaimana melaksanakan rencana, sebagaimana (2), and (4) bagaimana memeriksa kembali jawaban yang telah diberikan (Polya, 1973). Indikator tahapan pemecahan masalah Polya (Fahrudin, dkk, 2019; Kaliky, dkk, 2019) ada 4, yaitu (1) menuliskan dengan bahasa sendiri tantang apa diketahui dan ditanya, serta mengklasifikan informasi penting dan tidak penting untuk dijadikan sebagai dalam menentukan cara atau strategi; (2) membuat rencana atau ide tertulis yang akan dipergunakan menyelesaikan masalah; (3) melakukan (action) menjawab soal atau menyelesaikan permasalahan yang ada berdasarkan perencanaan yang telah dibuat sebelumnya; (4) memeriksa kembali step by step (see atau reflect) kebenaran jawaban yang diperoleh, dan memodifikasinya jika mungkin. Lebih lanjut, siswa perlu diberi latihan terus menerus (drill) untuk mengerjakan soal-soal yang menantang dan menuntun siswa berfikir tingkat tinggi (higher order thinking) agar kemampuan matematis siswa dalam menyelesaikan masalah 
semakin baik dan meningkat (Hidayati, 2017). Kemampuan pemecahan masalah juga diteliti kaitannya dengan gender dan gaya kognitif (Nur \& Palobo, 2018).

Gaya kognitif adalah proses yang dilakukan seseorang dalam menyimpan dan menerima informasi (data), yang akan dipergunakan olehnya dalam menanggapi dan menyelesaikan suatu persoalan. Gaya kognitif atau cognitive style adalah faktor dominan yang mempengaruhi hasil belajar siswa secara psikologis. Witkin (1977) memaparkan bahwa gaya kognitif ada 2 macam, yaitu field dependent (FD) dan field independent (FI). Kategori FD, jika ia seorang yang mampu berfikir menyeluruh atau global, memahami dan menerima struktur informasi atau data yang ada, berorientasi sosial, memilih profesi yang bersifat sosial, dan bercenderungan untuk sepakat dengan tujuan, informasi atau data yang sudah ada/tersedia. Seseorang dikategorikan mempunyai gaya kognitif FI, jika ia seorang yang mampu menganalisis secara mendalam tentang suatu obyek terpisah dari lingkungannya, mampu mengorganisasi obyek-obyek tersebut, dan yang terakhir adalah bersifat individual.

Ide baru dalam penelitian ini adalah dengan menggunakan soal jumping task (JT) sebagai instrumen pemecahan masalah. Pembelajaran yang menantang dapat diwujudkan dengan menerapkan JT dalam pembelajaran matematika tingkat tinggi. JT adalah soal yang bersifat aplikatif atau terapan yang menantang anak didik untuk kritis, kreatif, dan berfikir tingkat tinggi atau soal tersebut satu tingkat diatas soal pada tingkatan kurikulum yang dibahas pada saat itu (Nofrion, 2017). Hobri dkk. (2020) menyatakan bahwa JT adalah soal atau tugas dengan level atau tingkatan soal aplikasi atau terapan suatu topik tertentu, dan dapat berkembang kepada topik lain yang terkait (inter-twin). Tujuan dari memberikan JT adalah memberikan tantangan bagi siswa untuk berpikir kritis dan kreatif (HOTS) sehingga mereka terus mengembangkan proses berfikirnya dalam belajar matematika dan siswa dididik dan dibiasakan untuk berpikir secara mandiri (Saiful, dkk., 2019).

Sato (2015) menggambarkan JT sebagai higher level tasks berikut ini :

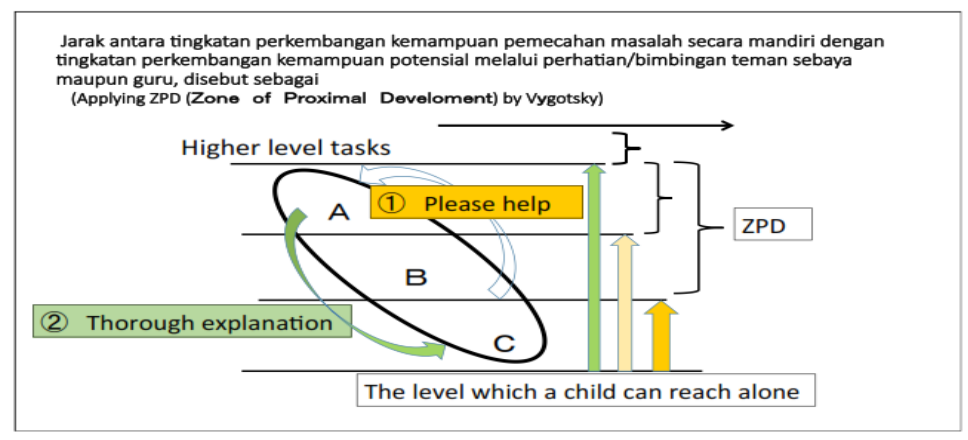

\section{Metode}

Gambar 1. Jumping Task sebagai higher level taks 
Penelitian ini dilaksanakan di kelas X MIPA 1 SMA Negeri 4 Jember. Subyek penelitian adalah seluruh siswa di kelas tersebut. Jenis penelitian ini adalah penelitian kualitatif-deskriptif. Data diperoleh dengan cara memberikan tes. Tes yang dipergunakan adalah tes GEFT yang diadopsi dari Shofia, dkk. (2017) yang mengelompokkan siswa ke dalam gaya kognitif FD dan FI. Pengelompokan tersebut berdasarkan pada Gordon dan Wyant (1994) dengan ketentukan, skor 0-11 adalah kategori FD dan skor 12-18 kategori FI. Setelah itu, berikan soal berbasis JT yang diberikan kepada semua siswa kelas X MIPA-1.

Hasil tes tersebut dianalisis untuk menentukan kriteria FD atau FI. Penentuan kriteria FD dan FI menggunakan 2 langkah berikut ini: (1) melakukan penskoran terhadap pekerjaan siswa dengan berpedoman pada rubrik penskoran, dan (2) pengolahan skor untuk menghitung nilai akhir dari keseluruhan permasalahan yang dikerjakan siswa. Setelah nilai akhir terkumpul, selanjutnya dilakukan wawancara (Ninik, dkk., 2014). Berdasarkan stratifikasi yang ditetapan Arikunto (2013), kriteria kemampuan pemecahan masalah dalam penelitian disajikan seperti Tabel 1 berikut ini.

Tabel 1. Stratifikasi Kriteria Pemecahan Masalah

\begin{tabular}{ccc}
\hline No & Nilai & Kriteria \\
\hline 1 & $80 \leq N A \leq 100$ & Baik sekali \\
2 & $66 \leq N A<80$ & Baik \\
3 & $56 \leq N A<66$ & Cukup \\
4 & $40 \leq N A<56$ & Kurang \\
5 & $0 \leq N A<40$ & Sangat Kurang \\
\hline
\end{tabular}

\section{Hasil Penelitian}

Validasi dilakukan terhadap instrumen tes (soal JT) dan terhadap panduan wawancana (interview). Hasil validasi menujukkan bahwa instrumen tersebut memenuhi kriteria valid. Dengan demikian, kedua instrumen tersebut dapat dijadikan sebagai instrumen penelitian dalam penelitian ini. Soal pemecahan masalah terdiri dari 2 soal uraian JT dengan level C-4 topik Sistem Persamaan Linier Tiga Variabel (SPLTV). Proses kognitif dalam menganalisis ada 3 macam, yaitu membedakan, mengorganisakan, dan mencari/memperoleh pesan tersirat. Indikator kemampuan analisis adalah: (1) kemampuan menyelidiki informasi atau data yang diterima, (2) kemampuan mengenali dan membedakan mana sebagai penyebab dan mana sebagi akibat (hubungan kausalitas), serta (3) melakukan identifikasi secara detail atau memformulasikan sesuatu (Nasrul, dkk., 2019). Pada masing-masing soal tersebut terdiri dari empat poin pertanyaan sesuai dengan indikator Polya, yaitu (1) dapat memahami 
(understanding) suatu masalah dengan benar, (2) melakukan perencanaan cara menyelesaikan permasalahan, (3) melaksanakan dengan konsisten dan luas berdasarkan rencana yang telah dibuat, dan (4) melakukan pemeriksaan kembali secara detail dan step-by-step atau merefleksi. Berikut adalah soal jumping task yang diberikan kepada siswa.

Seorang model memiliki penawaran untuk mempromosikan pakaian dari designer A, designer $\mathrm{B}$, dan designer $\mathrm{C}$ dalam waktu 1 bulan. Syarat yang diajukan oleh masing-masing perusahaan tersebut adalah "model harus mengiklankan produk dari designer tersebut saja, tidak diperbolehkan untuk menerima tawaran dari designer lain". Perbandingan gaji yang diberikan oleh designer $\mathrm{A}$ dan designer $\mathrm{B}$ untuk sekali peragaan adalah $2: 3$. Gaji dari designer $\mathrm{B}$ dan designer $\mathrm{C}$ berbanding $6: 5$. Gaji dari designer $\mathrm{A}$ dan $\mathrm{B}$ jika digabungkan adalah Rp 1.000.000,00 lebih banyak dari C. Bantulah model tersebut untuk memilih designer manakah yang harus ia pilih untuk mendapatkan gaji yang paling besar dengan menuliskan:

(a) Informasi apa yang dapat kalian peroleh dari permasalahan tersebut?

(b) Dapatkan kamu menjelaskan cara penyelesaian soal step by step?

(c) Tuliskan penyelesaian dari permasalahan tersebut berdasarkan rencana yang kalian ungkapkan pada poin $b$.

(d) Tunjukkan bahwa jawaban yang kalian peroleh benar.

Secara umum, gambar 2 berikut merupakan gambaran kemampuan pemecahan masalah siswa FD.

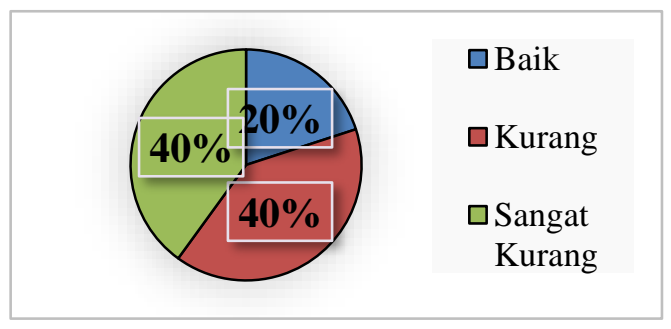

Gambar 2. Deskripsi kemampuan pemecahan masalah anak FD

Gambar 3 berikut merupakan jawaban subjek FD dengan kemampuan baik dalam menyelesaikan permasalahan, dilambangkan dengan $\mathrm{D}_{1}$.

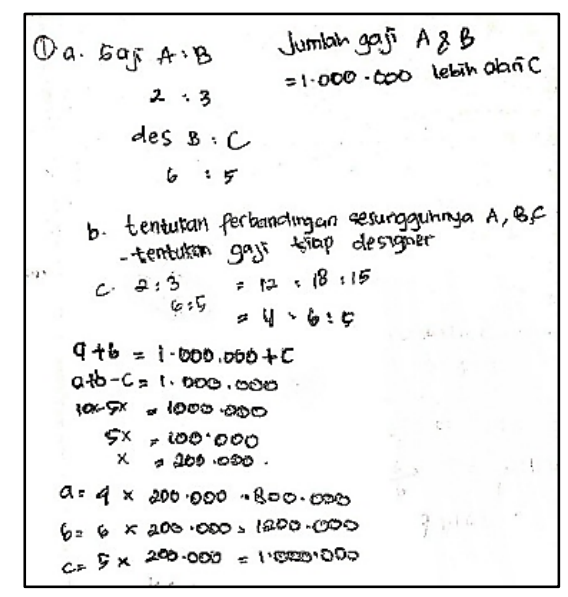

Gambar 3. Jawaban Siswa $D_{1}$ 
Untuk menggali pemahaman siswa $\mathrm{D}_{1}$ terhadap permasalahan, dilakukan wawancara. Berikut disajikan cuplikan transkrip wawancara dengan $\mathrm{D}_{1}$.

P101 Coba jelaskan informasi apa yang ditanyakan dari permasalahan 1 tersebut?

D101 Membantu model untuk memilih designer yang mempunyai gaji paling besar.

P102 Bagaimana cara kamu mendapatkan data tentang hal-hal yang bisa ditulis atau direkap?

D102 Dari soalnya bu dengan dibaca berulang-ulang.

P103 Pada saat kamu mengerjakan soal, dapatkan kamu menemukan atau mengklasifikan data-data atau informasi yang penting atau tidak penting?

D103 Tidak ada bu.

Pada tahapan memahami permasalahan, $\mathrm{D}_{1}$ mampu menuliskan informasi-informasi yang ada dan menuliskan pertanyaan yang merupakan re-write dengan lengkap menggunakan kalimat yang tidak jauh berbeda dengan soal. $\mathrm{D}_{1}$ mengubah yang apa yang diketahui kedalam kalimat matematika dengan menyertakan kalimat verbal seperti dalam soal. Kemampuan $\mathrm{D}_{1}$ dalam tahap memahami masalah termasuk dalam kriteria baik. Selanjutnya, pada tahap perencanaan, $\mathrm{D}_{1}$ dapat menuliskan rencana dengan benar, namun belum mampu menjelaskannya dengan lengkap. Subjek $\mathrm{D}_{1}$ menuliskan rencana dengan tidak terlepas dari latar belakangnya. Subjek $\mathrm{D}_{1}$ melihat masalah secara global. Berikut sebagian transkrip wawancara siswa $\mathrm{D}_{1}$ dalam tahap perencanaan.

P104 Tahukah kamu, nama metode yang digunakan dalam menjawab soal?

D104 Saya kurang faham namanya bu nanti itu nyari perbandingan dari A:B:C. Caranya 2 kali 6, 3 kali 3, 3 kali 5 diperoleh 12:18:15 kemudian disederhanakan jadinya 4:6:5. Terus dicari gaji masing-masing designer.

P105 Lalu $x$ disini sebagai apa ya dek?

D105 Apa ya bu namanya, saya tidak tahu, nanti itu dibuat mencari gajinya designer.

Subyek $D_{1}$ didalam tahap melaksanakan rencana penyelesaian telah mampu menunjukkan kinerja yang baik sesuai dengan rencana yang ada, ditunjukkan dengan hasil pekerjaannya benar. Begitu pual dengan proses pengerjaan soal, $\mathrm{D}_{1}$ tidak mengalami kesulitan. Kemampuan $\mathrm{D}_{1}$ dalam tahap melaksanakan rencana penyelesaian masuk dalam kriteria baik sekali. Selanjutnya, pada tahap memeriksa kembali, $\mathrm{D}_{1}$ menjelaskan cara memeriksa kembali yaitu membaca soal kembali (re-read), kemudian mencocokkan dengan yang ditanya, selanjutnya memeriksa langkah-langkah pengerjaannya sehingga menghasilkan kesimpulan yang benar bahwa model harus memilih designer $\mathrm{B}$. Namun, $\mathrm{D}_{1}$ belum mampu untuk membuktikan kebenaran jawaban yang diperoleh. Kemampuan $\mathrm{D}_{1}$ dalam tahap memeriksa kembali termasuk dalam kriteria cukup.

Siswa FD dengan kemampuan sangat kurang dilambangkan dengan $\mathrm{D}_{2}$. Berikut jawaban $\mathrm{D}_{2}$ dalam menyelesaikan soal JT. 


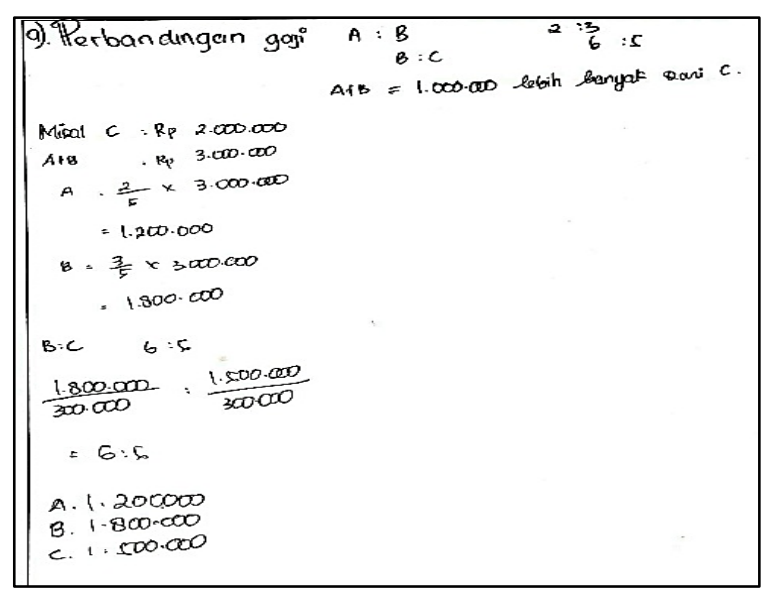

Gambar 4. Jawaban Siswa $\mathrm{D}_{2}$

Wawancara dengan siswa $\mathrm{D}_{2}$ dalam tahap memahami masalah, disajikan berikut ini.

P201 Pada permasalahan 1, dapatkan kamu menentukan, intinya bertanya tentang apa?

D201 Yang ditanyakan itu mencari designer dengan gaji paling besar.

P202 bagaimana cara kamu merangkum data-data dari soal?

D202 Dibaca.

P203 Menurut kamu, adakah data yang tidak diperlukan dalam soal tersebut?

D203 Tidak ada

Pada tahap memahami masalah, $\mathrm{D}_{2}$ telah mengidentifikasi dengan baik dan lengkap mengenai tentang informasi yang ada. Dalam menuliskan apa diketahui, $\mathrm{D}_{2}$ menulis dengan benar tentang besar gaji desainer A, B, dan C, begitu pula dengan apa yang ditanyakan atau pertanyaan/perintah dalam soal. Namun demikian $\mathrm{D}_{2}$ belum dapat membedakan mana data yang penting dan akan dipergunakan untuk menyelesaikan soal dan mana data yang tidak penting. Hal ini menunjukkan bahwa kemampuan $\mathrm{D}_{2}$ memahami masalah yang disajikan dalam dengan baik. Selanjutnya, pada tahap perencanaan, $\mathrm{D}_{2}$ menyebutkan rencana yaitu memisalkan gaji dari designer C sebesar Rp 2.000.000. Selanjutnya dicari gaji dari masingmasing designer dengan menggunakan konsep perbandingan. $\mathrm{D}_{2}$ belum mampu menjelaskan rencana penyelesaian dengan lengkap. Kemampuan $\mathrm{D}_{2}$ dalam tahap merencanakan penyelesaian dalam kategori kurang. Berikut sebagian transkrip wawancara subjek $\mathrm{D}_{2}$ pada tahap perencanaan.

P204 Bagaimana cara atau metode yang kamu siapkan untuk menyelesaikan soal?

D204 Dimisalkan dulu C nya terus dicari gaji dari designernya pakai cara perbandingan.

P205 Mengapa C nya dimisalkan 2 juta?

D205 Biar lebih mudah untuk menghitungnya.

P206 Jika C nya dimisalkan dengan yang lain apakah boleh?

D206 Iya kayaknya boleh.

Subyek $\mathrm{D}_{2}$ telah dapat menyelesaikan soal kemampuan pemecahan masalah berdasarkan rencana yang telah dibuat sebelumnya. Namun demikian, hasil pekerjaannya salah, 
dikarenakan rencana yang dibuat juga salah. Dapat dikatakan bahwa kemampuan $\mathrm{D}_{2}$ dalam tahap melaksanakan langkah-langkah penyelesaian sesuai rencana berada dalam kriteria sangat kurang. Selanjutnya, pada tahap memeriksa kembali, $\mathrm{D}_{2}$ tidak memeriksa kembali (recheck) sehingga berdampak pada kesimpulan yang salah. Selain itu, $\mathrm{D}_{2}$ juga belum mampu membuktikan kebenaran jawaban yang diperoleh. Kemampuan $\mathrm{D}_{2}$ sangat kurang dalam melakukan pemeriksaan kembali atau check and re-check.

Hasil penelitian selanjutnya adalah deskripsi kemampuan siswa FI. Diagram lingkaran berikut menyajikan hal tersebut.

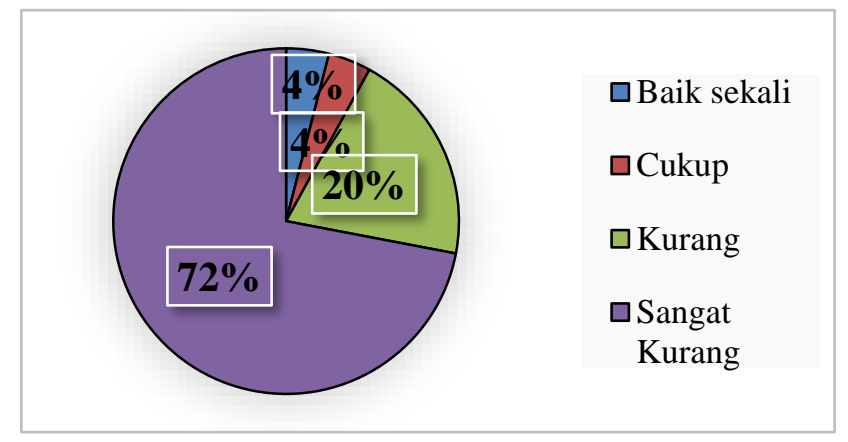

Gambar 5. Persentase tingkat kemampuan anak FI dalam menyelesaikan soal JT

Ada 1 orang siswa FI (4\%) yang memiliki kemampuan baik sekali. Subjek FI yang masuk kedalam kategori baik sekali adalah siswa yang dapat memperoleh nilai akhir 87,5 dari total permasalahan yang diberikan. Pemenuhan indikator pemecahan masalah Siswa FI baik sekali dilambangkan dengan $\mathrm{I}_{1}$. Jawaban subjek $\mathrm{I}_{1}$ disajikan berikut.

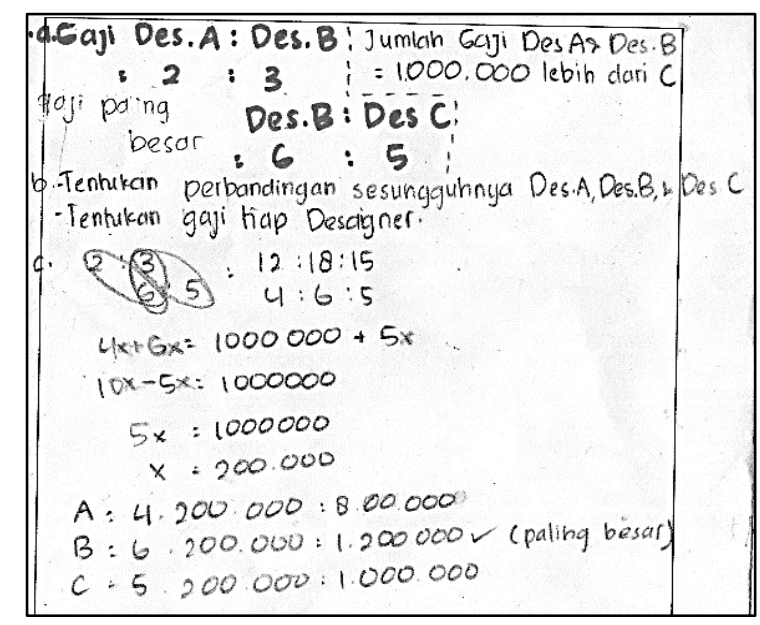

Gambar 6. Jawaban Siswa $I_{1}$

Untuk menggali pemahaman siswa terhadap permasalahan, dilakukan wawancara sebagai berikut. 
P101 Menurut kamu, data apa saja yang tidak diperlukan dalam menyelesaikan permasalahan 1?

I101 Ada bu yang designer memberikan waktu 1 bulan.

P102 Bagaimana cara kamu menentukan mana informasi yang akan ditulis sebagai data yang diketahui dan juga bagaimana cara kamu menentukan mana informasi yang akan ditulis sebagai data yang ditanyakan?

I102 Dibaca soalnya bu, terus dipahami.

Subyek $\mathrm{I}_{1}$ memahami masalah dengan benar. Hal ini dibuktikan dengan kemampuannya dalam merangkum informasi dari soal yang diberikan. Juga memahami apa pertanyaan dan maksud pertanyaan secara komprehensif. $I_{1}$ juga dapat membedakan dengan tepat mana data utama dan sangat diperlukan untuk menyelesaikan soal dan mana data yang kurang atau tidak esensial atau tidak terlalu berkaitan dengan penyelesaian soal. Kemampuan siswa $\mathrm{I}_{1}$ dalam memahami masalah masuk dalam kriteria baik sekali. Selanjutnya, pada tahap merencanakan penyelesaian, $I_{1}$ dapat menjelaskan rencana penyelesaian dengan benar, yaitu dengan menentukan perbandingan sesungguhnya dari designer A, B, dan C. Kemudian menentukan hasil perbandingan yang selanjutnya akan digunakan untuk mencari gaji tiap designer. Selain itu, $I_{1}$ juga mampu menjelaskan rencana dengan lengkap. $I_{1}$ dalam merencanakan penyelesaian mampu memilih konsep-konsep matematika, terutama kaitannya dengan SPLTV dengan tepat dalam menyelesaikan masalah tersebut.

Siswa $I_{1}$ dapat merealisasikan dengan baik rencana yang telah disiapkan dan hasil pekerjaannya benar. $I_{1}$ dalam melaksanakan rencana yaitu mampu menerapkan tahapantahapan dan konsep pemecahan sehingga memperoleh hasil yang benar. Kemampuan siswa $\mathrm{I}_{1}$ melaksanakan rencana penyelesaian berada dalam kriteria baik sekali. Selanjutnya, pada tahap memeriksa kembali, siswa $I_{1}$ menjelaskan cara memeriksa kembali yaitu dengan membaca kembali dengan detail tentang pertanyaan soal, kemudian dicocokkan dengan jawaban yang telah dilakukan, dengan melakukan verifikasi jawaban melalui substitusi. Namun, siswa $\mathrm{I}_{1}$ belum mampu membuktikan kebenaran jawaban yang diperoleh. Siswa $I_{1}$ dalam tahap memeriksa kembali termasuk dalam kriteria cukup. Berikut cuplikan transkripsi wawancara dengan siswa $\mathrm{I}_{1}$.

P112 Apakah kamu melakukan pemeriksaan terhadap jawaban yang diperoleh?

I112 Iya bu. Itu kan sudah ketemu nilainya. Terus dikoreksi lagi soalnya itu apa yang ditanyakan itu apa. Nah yang ditanyakan itu kan gaji yang paling besar, jadi dilihat yang paling besar ternyata B. Jadi jawabannya designer $B$ yang paling besar.

P113 Terus ini ada tanda centang maksudnya apa dek?

I113 Oh itu jawaban yang benar bu.

P114 Lalu apa yang dapat kamu simpulkan dari hasil yang diperoleh?

I114 Kesimpulannya itu tahu gaji yang paling besar diantara designer A, B, dan C. Jadi, yang paling banyak itu gaji dari designer B sebesar 1.200.000. 
Siswa FI yang memiliki kemampuan sangat kurang ada 18 orang (72\%). Subjek FI yang masuk kedalam kategori sangat kurang adalah siswa yang dapat memperoleh nilai akhir 37,92 dari total permasalahan yang diberikan. Siswa FI dengan kemampuan sangat kurang dilambangkan dengan $\mathrm{I}_{2}$.

Berikut ini siswa $\mathrm{I}_{2}$ menjawab soal dengan langkah-langkah Polya.

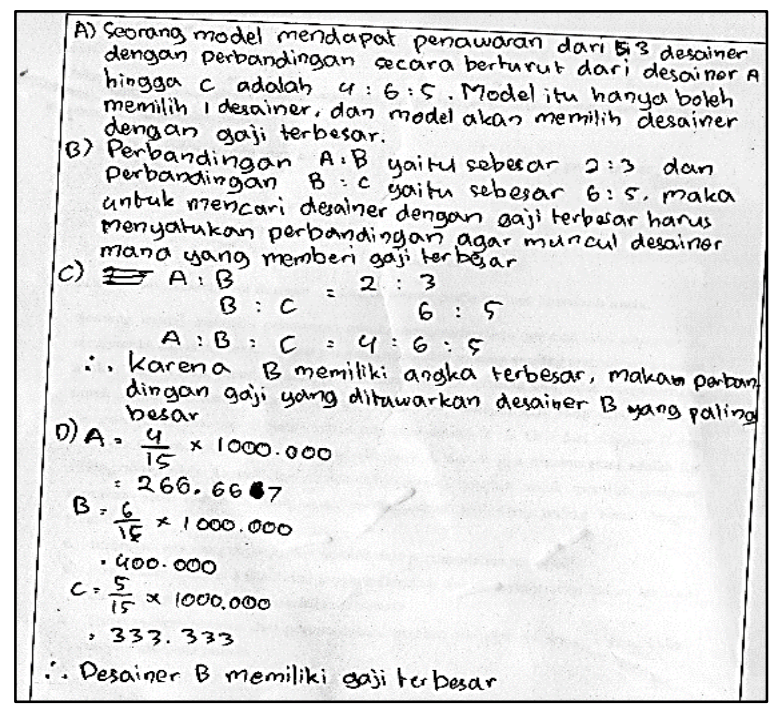

Gambar 7. Tulisan tangan Siswa $I_{2}$ dalam menjawab soal

Pada tahap memahami masalah seperti yang terlihat pada Gambar 6, subyek $\mathrm{I}_{2}$ sudah dapat membuat kalimat sendiri dalam mengekspresikan daya yang ada di soal, akan tetapi esensinya masih sama dengan kalimat dalam soal. Dalam menuliskan apa yang ditanyakan, subyek $\mathrm{I}_{2}$ udah menulis dengan tepat walaupun berbeda redaksi. Deskripsi pemecahan masalah siswa $I_{2}$ hampir sama dengan $D_{2}$, namun berbeda pada tahapan perencanaan serta pelaksanaannya. Siswa $\mathrm{I}_{2}$ merencanakan dengan detail dan rinci bagaimana strategi penyelesaian yang digunakan. Rencana penyelesaiannya adalah dengan menggabungkan perbandingan $\mathrm{A}, \mathrm{B}$, dan $\mathrm{C}$ agar muncul designer mana yang memberi gaji terbesar. Selanjutnya dicari nilai perbandingan tertinggi. Nilai tertinggi tersebut menunjukkan designer yang memberi gaji terbesar. Siswa $\mathrm{I}_{2}$ mampu menjelaskan rencana penyelesaian dengan baik, namun rencana yang diungkapkan belum tepat karena memberikan hasil yang salah. Siswa $\mathrm{I}_{2}$ dalam tahap merencanakan penyelesaian termasuk dalam kriteria cukup.

P208 Teknik atau bagaimana cara yang kamu lakukan untuk menyelesaikan soal?

I208 Ditentukan perbandingannya dulu.

P209 Maksudnya bagaimana? 
I219 Perbandingannya disamakan.Pakai yang gini (dengan menunjuk lembar jawaban), terus bawahnya $6: 5$. Jadi, $4: 6: 5$.

P211 Cara dapat $4: 6: 5$ bagaimana?

I211 2 dikalikan 6 kan 12, 3 dikali 6 kan 18, terus 3 dikali 5 itu 15. Berarti 12:18:15 terus di sederhanakan jadinya $4: 6: 5$.

Selanjutnya, kemampuan $\mathrm{I}_{2}$ dalam melaksanakan rencana penyelesaian. Siswa $\mathrm{I}_{2}$ menjelaskan langkah-langkah atau yang dipergunakan yaitu dengan mencari perbandingan dari A:B:C, kemudian untuk mencari besar gaji dari masing-masing designer digunakan rumus $A=\frac{4}{15} \times 1000000, B=\frac{6}{15} \times 1000000, \quad C=\frac{5}{15} \times 1000000$. Selanjutnya, dicari gaji yang terbesar. Cara tersebut menghasilkan besar gaji yang salah dan siswa $I_{2}$ menyadari kesalahan yang dilakukan. Siswa $\mathrm{I}_{2}$ tidak mampu melaksanakan rencana penyelesaian dengan baik dan konsisten sehingga hasil pekerjaannya salah. Siswa $\mathrm{I}_{2}$ dalam tahap melaksanakan rencana penyelesaian termasuk dalam kriteria sangat kurang.

Sesuai dengan penjabaran di atas, siswa FI lebih mampu untuk menguraikan permasalahan yang diberikan. Seperti yang dilakukan oleh siswa $\mathrm{I}_{1}$. Permasalahan yang diberikan sesuai dengan karakter soal JT dimana dalam penelitian ini adalah soal level C4 yang memerlukan kemampuan untuk menganalisis informasi-informasi yang dibutuhkan dalam memecahkan masalah. Siswa $I_{1}$ mampu menguraikan data yang diberikan sebagai informasi utama yang sangat penting untuk penyelesaian soal, dan juga mampu mengklasifikasi data dalam soal sebagai informasi tambahan saja atau tidak begitu penting. Hal ini menunjang siswa dalam nenetapkan strategi pemecahan masalah. Hal demikian tidak terjadi pada subjek FD, dimana subjek FD belum mampu menguraikan data soal sebagai informasi yang penting dan tidak penting. Secara umum, subjek FI lebih baik kemampuannya jika dibandingkan dengan siswa FD. Siswa FI adalah yang tertinggi dengan kategori baik sekali, sedangkan siswa FD kategorinya baik. Jika ditelusur lebih jauh, hasil penelitian ini sesuai dengan penelitian Prabawa dan Zaenuri (2017) dimana dijelaskan adanya kecenderungan siswa FI lebih baik daripada siswa FD terkait dengan kemampuan pemecahan masalah.

\section{Pembahasan}

Subyek $\mathrm{D}_{1}$ memahami masalah dengan baik dan menuliskan informasi-informasi dalam soal dengan lengkap menggunakan kalimat sendiri, begitu pula dengan apa yang ditanyakan. Namun, kalimat yang dibuat sendiri oleh $\mathrm{D}_{1}$ tidak jauh berbeda dengan soal. $\mathrm{D}_{1}$ mengubah 
yang apa yang diketahui kedalam kalimat matematika dengan menyertakan kalimat verbal seperti dalam soal. Hasil ini sejalan dengan Marwazi, dkk. (2019). Pada penelitian tersebut ditunjukkan bahwa dalam memahami masalah, subjek FD sudah mempunyai kemampuan menuliskan data dan informasi di soal kedalam kalimat matematika, namun kalimatnya mirip dengan yang ada dalam pertanyaan. Pada tahap ini, FD belum mampu membedakan data yang penting dan tidak penting, artinya masih rancu. Kemampuan $\mathrm{D}_{1}$ dalam tahap memahami masalah termasuk dalam kriteria baik. Selanjutnya, pada tahap perencanaan, $D_{1}$ dapat menuliskan dengan benar dan detail tentang rencana yang digunakan, namun belum mampu menjelaskan dengan lengkap. Subjek $\mathrm{D}_{1}$ melihat masalah secara global. Hal ini sebagimana dikemukan oleh Witkin (1977), bahwa siswa FD adalah siswa yang cenderung menerima secara dominan pada bagian/parsial atau konteks. Berdasarkan hasil penelitian, terlihat bahwa kemampuan $\mathrm{D}_{1}$ dalam tahap merencanakan penyelesaian termasuk dalam kriteria baik (Afifah, dkk., 2019; Panjaitan, 2018).

Subjek $I_{1}$ dalam memahami masalah sudah baik yang ditunjukkan dengan dapat menuliskan hal-hal apa yang ada yang terulis di soal serta memahami pertanyaan yang ditanyakan, bahkan menuliskanya secara lengkap. Subjek $\mathrm{I}_{1}$ juga mampu mengklasifikasikan mana informasi yang penting dan berguna untuk penyelesaian soal dan mana yang tidak penting. Siswa $I_{1}$ dalam memahami masalah termasuk kriteria baik sekali. Subyek $I_{1}$ dapat menjelaskan rencana yang digunakan dengan benar, yaitu dengan menentukan perbandingan sesungguhnya dari designer A, B, dan C. Kemudian menentukan hasil perbandingan yang selanjutnya akan digunakan untuk mencari gaji tiap designer. Selain itu, $\mathrm{I}_{1}$ juga mampu menjelaskan rencana dengan lengkap. $\mathrm{I}_{1}$ dalam merencanakan penyelesaian mampu memilih konsep yang tepat untuk menyelesaikan masalah. Penelitian Tisngati (2015) menunjukkan bahwa siswa FI memiliki karakter berpikir reflektif, yaitu : (1) mampu menyeleksi atau memilih/memilah ilmu pengetahuan yang ada, dan (2) dapat membuat pertimbangan yang matang dalam merencanakan pemecahan masalah secara aktif. Siswa $\mathrm{I}_{1}$ dalam tahap merencanakan penyelesaian termasuk dalam kriteria baik sekali (Afifah, dkk., 2019; Panjaitan, 2018). Siswa $I_{1}$ mampu melaksanakan rencana dengan baik sehingga memperoleh hasil yang benar. $\mathrm{I}_{1}$ dalam melaksanakan rencana penyelesaian yaitu mampu menerapkan cara-cara pemecahan masalah terintegrasi dengan konsep yang telah direncanakan sebelumnya. Keberhasilan subjek FI dalam menyelesaikan masalah dengan tepat dikarenakan peencanaan yang akurat (Lusiana, 2017). Kemampuan siswa $\mathrm{I}_{1}$ dalam melaksanakan rencana 
penyelesaian termasuk dalam kriteria baik sekali. Subyek $\mathrm{I}_{2}$ diidentifikasi memahami masalah dengan baik melalui tulisan yang dihasilkan tentang apa diketahui dalam soal dengan menggunaan kalimat sendiri yang berbeda dengan kalimat yang ada di soal. Hal ini karena individu FI dapat menggunakan strukturnya sendiri untuk menemukan dan memproses informasi dengan baik (Witkin,1977).

Sesuai dengan penjabaran diatas, siswa FI lebih mampu untuk menguraikan permasalahan yang diberikan. Seperti yang dilakukan oleh siswa $I_{1}$. Permasalahan yang diberikan sesuai dengan karakter soal JT (soal level C4) yang memerlukan kemampuan untuk menganalisis informasi yang dibutuhkan. Siswa $I_{1}$ mampu untuk menguraikan informasi bermakna sebagai bahan penting penyelesaian masalah dan tidak penting. Hal ini tidak terjadi pada subjek FD. Subjek FD belum mampu menguraikan informasi yang diberikan dalam soal menjadi informasi yang penting dan tidak penting. Individu FI mampu melakukan analisis dan mengurai objek terpisah dari lingkungannya dengan baik (Witkin, 1977). Subjek FI mempunyai kemampuan dalam menyelesaikan soal lebih baik dan lebih teliti jika dibandingkan dengan subjek FD. Kemampuan subyek FI berada pada kategori tertinggi dengan kriteria baik sekali dalam kemampuan pemecahan masalah, sedangkan subjek FD kategorinya baik (Prabawa \& Zaenuri, 2017).

Soal yang dipergunakan dalam penelitian adalah soal JT. Hasil analisis mendalam terhadap penggunaan soal JT sebagai soal pemecahan masalah, dijelaskan berikut ini: (1) kemampuan siswa pada tahap memahami masalah JT lebih rendah atau kurang detail jika dibandingkan dengan soal penyelesaian biasa, baik siswa FD ataupun FI, (2) pada tahap merencanakan penyelesaian, lebih rinci siswa FI jika dibanding siswa FD dalam menyelesaiakan soal baik soal JT maupun pemecahan masalah biasa, (3) kemampuan siswa FD pada tahap melaksanakan penyelesaian masalah JT hampir sama atau tidak jauh berbeda dengan siswa FI, (4) jika dibandingkan dengan pengunaan soal pemecahan masalah yang diperguanakan selama ini, penggunaan soal JT memberikan gambaran kemampuan penyelesaian soal yang relatif sama.

\section{Simpulan}

Siswa FD dalam menyelesaikan soal JT melalui tahapan Polya yaitu mampu menuliskan informasi di soal secara lengkap, cukup mampu mengklasifikasikan informasi penting/tidak, cenderung untuk membaca soal kembali dan mencocokkannya dengan hasil yang diperoleh tanpa mengecek langkah pengerjaan untuk memeriksa kembali. Perbedaan antara siswa FD 
yang berkemampuan baik dan sangat kurang yaitu pada perencanaan dan realisasi rencana penyelesaian. Siswa FD berkemampuan baik, dapat membuat renana penyelesaian dengan baik, realisasi pemecahan masalah baik, dan kesimpulan yang diungkapkan juga benar. Sedangkan siswa FD yang berkemampuan sangat kurang belum mampu merencanakan penyelesaian dengan benar, prosedur yang digunakan pada tahap melaksanakan rencana kurang tepat, sehingga kesimpulan yang diungkapkan kurang tepat.

Siswa FI dalam menyelesaikan soal JT melalui tahapan Polya yaitu dapat mengidentifikasi dan merinci hal-hal yang diketahui dalam soal, dan juga menuliskan kembali pertanyaan secara detail, cenderung untuk melihat kembali dan menganalisis apa yang ditanyakan, memeriksa kembali seluruh jawaban yang ditulis. Siswa FI yang berkemampuan baik sekali dan sangat kurang memiliki perbedaan dalam indikator membedakan informasi yang penting dan tidak, tahap merencanakan penyelesaian dan tahap melaksanakan rencana penyelesaian. Siswa FI yang berkemampuan baik sekali mampu mengklasifikan data yang bermmaka dan tidak, membuat rencana penyelesaian dengan baik, mengerjakan soal dengn benar sesuai rencana, dan kesimpulan yang diungkapkan juga benar. Sedangkan siswa FI yang berkemampuan sangat kurang cukup mampu membedakan informasi yang penting dan tidak, belum mampu merencanakan penyelesaian dengan benar, prosedur yang digunakan pada tahap melaksanakan rencana kurang tepat, sehingga kesimpulan yang diungkapkan kurang tepat.

\section{Referensi}

Afifah, D. S. N. \& Nafi'an, M. I. (2017). Onto-semiotic approach profile of senior high school on cognive style in solving statistical problems. Proceeding of International Conference on Mathematics, Science, and Education (ICMSE) 2016. 3(1) 2017. 110113.

Arikunto, S. (2013). Dasar-dasar evaluasi pendidikan edisi 2. Jakarta: Bumi Aksara.

Fahrudin, D. Mardiyana, \& Pramudya. I (2019) The analysis of mathematic problem solving ability by polya steps on material trigonometric reviewed from self-regulated learning. Journal of Physics: Conference Series $1254 \quad$ (2019) 012076. 1-6. https://doi.org/10.1088/1742-6596/1254/1/012076.

Gordon, H. R. \& Wyant, L. J. (1994). Cognitive style of selected international and domestic graduate students at Marshall University. Diakses dari http://eric.ed.gov/ericdocs/data/ ericdocs2sql/content_storage_01/000019b/80/13/e8/ic.pdf pada 15 Januari 2019.

Hidayati, A. U. (2017). Melatih keterampilan berpikir tingkat tinggi dalam pembelajaran matematika pada siswa sekolah dasar. Terampil, Jurnal Pendidikan dan Pembelajaran Dasar, 4(2), 143-156. https://doi.org/10.24042/terampil.v4i2.2222.

Hobri. (2020). Lesson study for learning community: penerapan dan riset dalam pembelajaran matematika. Yogyakarta: LaksBang PRESSindo. 
Hobri, Ummah, I. K., Yuliati, N., \& Dafik. (2020). The effect of jumping task based on creative problem solving on student's problem solving ability. International Journal of Instruction, 13(1), 387-406. https://doi.org/10.29333/iji.2020.13126a.

Kaliky, Nurlaelah, E. \& Aljupri. (2019). Analysis of mathematical problem solving ability students of junior high school to Polya model S H. Journal of Physics: Conference Series, 1157(2019) 042064, 1-3. https://doi.org/10.1088/1742-6596/1157/4/042064.

Krulik, S. \& Rudnick, J. A. (1995). The new sourcebook for teaching reasoning and problem solving in elementary school. Needham Heights: Allyn \& Bacon.

Lusiana, R. (2017). Analisis kesalahan mahasiswa dalam memecahkan masalah pada materi himpunan ditinjau dari gaya kognitif. Jurnal Penelitian dan Pembelajaran Matematika, 10(1), 24-29. https://doi.org/10.30870/jppm.v10i1.1290.

Marwazi, M., Masrukan, M., \& Putra, N. M. D. (2019). Analysis of problem solving ability based on field dependent cognitive style in discovery learning models. Journal of Primary Education, 8(2), 127-134. https://doi.org/10.15294/jpe.v8i2.25451.

Nasrul, Hobri, \& Oktavianingtyas, E. (2019). Analisis kemampuan berpikir tingkat tinggi siswa sekolah menengah di Jember dalam menyelesaikan soal peluang pada pembelajaran berbasis lesson study learning community berdasarkan kecerdasan emosional. Jurnal Matematika dan Pendidikan Matematika, 10(1), 1-12. https://doi.org/10.19184/kdma.v10i1.11653.

Ninik, Hobri, \& Suharto. (2014). Analisis kemampuan pemecahan masalah untuk setiap tahap model Polya dari siswa SMK IBU Pakusari Jurusan Multimedia pada pokok bahasan program linier. Kadikma, 5(3), 61-68.

Nofrion. (2017). Peningkatan aktivitas belajar siswa melalui penerapan metode "jumping task" pada pembelajaran geografi. Jurnal Geografi, 9(1), 11-20. https://doi.org/10.24114/jg.v9i1.6043.

Nur, A.S. \& Palobo, M. (2018). Profil kemampuan pemecahan masalah matematika siswa ditinjau dari perbedaan gaya kognitif dan gender. Jurnal Matematika Kreatif - Inovatif, 9(2), 139-148.

OECD. (2019). Combined Executive Summaries PISA 2018. Paris: OECD. Diakses dari https://www. oecd.org/pisa/Combined_Executive_Summaries_PISA_2018.pdf\&ved=2ahUKEwiUeXkpJfohVIWHOKHYPeBLAQFjAGegQIBBAP\&usg pada 6 Desember 2019.

Panjaitan, B. (2018). The reflective abstraction profile of junior high school students in solving mathematical problems based on cognitive style of field independent and field dependent. Journal of Physics: Conference Series, 1088(2018) 012094, 1-5. https://doi.org/10.1088/1742-6596/1088/1/012094.

Panjaitan, M., \& Rajagukguk, S. (2017). Upaya meningkatkan kemampuan pemecahan masalah matematika siswa dengan menggunakan model pembelajaran problem based learning di kelas X SMA. Jurnal Inspiratif, 3(2), 1-17. https://doi.org/10.24114/jpmi.v3i2.8880.

Polya, G. (1973). How to solve it: a new aspect of mathematical method. New Jersey: Princeton University Press.

Prabawa, A. P. \& Zaenuri. (2017). Analisis kemampuan pemecahan masalah ditinjau dari gaya kognitif siswa pada model project based learning bernuansa etnomatematika. Unnes Journal of Mathematics Education Research, 6(1), 120-129.

Saiful, Susanto, \& Hobri. (2019). The students' metacognition analysis through jumping task based on lesson study for learning community. Journal of Physics: Conference Series, 1265(1) 1-8. https://doi.org/10.1088/1742-6596/1265/1/012002. 
Sato, M, (2015). How do Teachres Turn to be Learning Professional? Lesson Study in School as Learning Community, Materi dalam Short Term on Lesson Study (STOLS) V for ITTEP (Institutes of Teachers Training and Education Personnel), 27 September sampai dengan 23 Oktober 2015. Tokyo: Japan International Cooperation Agency.

Shofia, E. A. L., Hobri, \& Murtikusuma, R. P. (2018). Analisis kemampuan berpikir kreatif siswa pada materi aritmatika sosial berbasis jumping task ditinjau dari gaya kognitif field dependent dan field independent. Jurnal Matematika dan Pendidikan Matematika, 9(3), 171-182. https://doi.org/10.30659/kontinu.3.1.37-50.

Tambychik, T. \& Meerah, T. S. (2010). Students' difficulties in mathematics problemsolving: what do they say? Procedia Social and Behavioral Sciences, 8(2010), 142-151. https://doi.org/10.1016/j.sbspro.2010.12.020.

Tisngati, U. (2015). Proses berpikir reflektif mahasiswa dalam pemecahan masalah pada materi himpunan ditinjau dari gaya kognitif berdasarkan langkah Polya. Beta Jurnal Tadris Matematika, 8(2), 115-124.

Witkin, H., Moore C., Goodenough, D., \& Cox, P. (1977). Field dependent and field independent cognitive styles and their educational implications. Review of Educational Research, 47(1), 1-64. https://doi.org/10.3102/00346543047001001. 